\title{
PENGEMBANGAN KREATIVITAS DALAM BUKU PELAJARAN KERAJINAN TANGAN DAN KESENIAN UNTUK SISWA KELAS 5 SD
}

\author{
Ika Lestari
}

\begin{abstract}
The objective of this research is to describe the aspects of creativity in Keratin Tongan Dan Keening (Handcraft and Arts), a main textbook, used in the fifth grade of Elementary School. The aspects of creativity are identified as personality, motivator, process and product. This research employed 2 content analysis method based on the data gathered by studying the whole book. It is found out that this book does not contain all aspects of creativity as expected in a textbook for Handcraft and Arts. This research, therefore, suggests some recommendation for writing a textbook for Handcraft and Arts.
\end{abstract}

Keywords: textbook, creativity, personality, process, product.

\section{PENDAHULUAN}

Untuk mendukung pendidikan yang berkualitas perlu tersedia sumber belajar. Ketersediaan sumber belajar dipandang perlu untuk mutu dan proses hasil pembelajaran. Sebagai sumber belajar, buku dapat memberikan isi atau pesan yang sesuai dengan perkembangan ilmu pengetahuan dan teknologi. Guru menyadari betapa penting dan strategisnya peran buku pelajaran dalam proses pembelajaran serta memiliki tanggung jawab untuk mengajarkan informasi yang ada di buku pelajaran.

Buku pelajaran sebagai bahan ajar hendaknya disusun selengkap dan sejelas mungkin, susunannya teratur dan sistematis, jenisnya bervariasi dan kaya akan informasi, serta memiliki daya tarik yang kuat sesuai dengan minat siswa bahkan untuk memenuhi kebutuhan siswa. Lebih dari itu, buku pelajaran bersifat menantang, merangsang, serta menunjang aktivitas dan kreativitas siswa. Selain buku pelajaran yang digunakan untuk menunjang kreativitas siswa, guru juga merupakan tokoh utama yang dinilai bertanggungjawab untuk mengembangkan kreativitas siswa.

Selama ini pendidikan di sekolah terkesan mementingkan pengembangan nalar dan kurang pada pengembangan kreativitas. Peserta didik cenderung dituntut untuk memberikan jawaban yang benar menurut guru dan kurang diberi kesempatan untuk memberikan alternatif-alternatif jawaban tertentu yang dapat menumbuhkan kreativitasnya.

Kerajinan Tangan dan Kesenian (KTK) merupakan salah satu mata pelajaran dalam GBPP Kurikulum 2004 yang memberikan kesempatan kepada siswa untuk memperoleh pengalaman berapresiasi dan berkreasi serta menghasilkan suatu produk yang bermanfaat langsung. Mata pelajaran
KTK tidak menuntut anak untuk menghafal berbagai teori, tetapi melakukan olah imajinasi dan kreativitas selaras dengan gerak, sehingga keseimbangan emosi dan perkembangan otak dapat tercapai.

Pernyataan di atas merupakan hal yang yang menarik untuk diteliti, sejauh mana pendekatanpendekatan pengembangan kreativitas terdapat dalam buku pelajaran KTK terbitan Yudhistira. Buku tersebut diharapkan dapat membantu guru dalam mengembangkan kreativitas siswa di sekolah.

Berdasarkan latar belakang masalah diatas, maka rumusan masalah pada penelitian ini, yaitu: sejauh mana pendekatan-pendekatan pengembangan kreativitas terdapat dalam buku pelajaran KTK untuk siswa kelas 5 SD?

\section{KAJIAN TEORITIK}

\section{Hakikat Kreativitas}

Kreativitas yang dimiliki manusia lahir bersamaan dengan lahirnya manusia itu. Secara semantik, Kamus Besar Bahasa Indonesia memberikan makna kreativitas sebagai "kemampuan untuk mencipta; daya cipta"(KBBI, 2001: 599). Makna itu menunjukkan bahwa kreativitas berkaitan dengan kesanggupan untuk melakukan suatu tindakan yang dimiliki seseorang untuk membuat kreasi baru yang diwujudkan dalam bentuk pikiran dan atau benda. Kreativitas tidak saja dianggap sebagai daya cipta. Kreativitas memiliki jangkauan yang lebih luas. Seperti pengertian kreativitas yang dikemukakan oleh Edy TS dan Yuli Astuti dan dikutip oleh Haryati (2003) bahwa "kreativitas adalah kemampuan untuk menghubungkan masalah yang satu dengan yang lainnya dan membuat analisa yang tepat." Pengertian ini menunjukkan bahwa kreativitas berkaitan dengan kemampuan berusaha menemukan hubungan- 
hubungan baru yang timbul dari adanya masalah. Sedangkan menurut Guilford seperti dikutip oleh Nashori dan Mucharam (2002) mengungkapkan bahwa "kreativitas adalah kemampuan berpikir divergen untuk menjajaki bermacam-macam alternatif jawaban terhadap suatu persoalan, yang sama benarnya."

Berdasarkan beberapa pengertian di atas, maka dapat didefinisikan bahwa kreativitas adalah kesanggupan seseorang untuk melakukan suatu tindakan yang tidak hanya memiliki daya cipta untuk membuat suatu kreasi baru tetapi juga mampu memberikan berbagai gagasan dalam menghadapi suatu persoalan atau memecahkan masalah. Kreativitas yang ada merupakan gabungan dari kemampuan berpikir kreatif dan kemampuan bersikap kreatif.

\section{Ciri-ciri Kreativitas}

Pada dasarnya, manusia itu mempunyai potensi untuk kreatif. Untuk dapat menumbuhkan dan mengembangkan sikap kreatif tentunya perlu diketahui terlebih dahulu ciri-ciri orang kreatif.

Setelah melakukan penelitian mengenai kreativitas, Guilford dalam Nashori dan Mucharam (2002) menemukan beberapa faktor penting yang merupakan ciri kemampuan berpikir kreatif. Pertama, kelancaran berpikir yaitu kemampuan untuk menghasilkan banyak ide yang keluar dari pemikiran seseorang. Kedua, keluwesan berpikir yaitu kemampuan untuk dapat melihat suatu masalah dari sudut pandang yang berbeda-beda dan mampu menggunakan bermacam-macam cara pemikiran. Ketiga, elaborasi yaitu kemampuan dalam mengembangkan gagasan dan memperinci detil-detil dari suatu objek sehingga menjadi lebih menarik. Keempat, keaslian yaitu kemampuan untuk mencetuskan gagasan unik. Kelima, evaluasi yaitu kemampuan untuk menentukan pendekatan penilaian dan menganalisis masalah dengan selalu bertanya.

Namun, dengan memiliki ciri-ciri di atas belum menjamin perwujudan kreativitas seseorang. Menurut Munandar (1992), ciri-ciri lain dari orang kreatif adalah menyangkut sikap dan perasaan seseorang, yang disebut dengan ciri-ciri afektif kreativitas. Ciriciri afektif kreativitas adalah rasa ingin tahu, tertarik terhadap tugas-tugas yang sulit, berani mengambil resiko, tidak mudah putus asa, menghargai keindahan, mempunyai rasa humor, ingin mencari pengalamanpengalaman baru, dan dapat menghargai baik diri sendiri maupun orang lain.

\section{Pengembangan Kreativitas}

Makna kreativitas pada penelitian ini adalah kesanggupan seseorang untuk melakukan suatu tindakan yang tidak hanya memiliki daya cipta untuk membuat suatu kreasi baru tetapi juga mampu memberikan berbagai gagasan dalam menghadapi suatu persoalan atau memecahkan masalah. Dengan demikian, maka makna pengembangan kreativitas yaitu serangkaian pendekatan yang membantu siswa untuk mengembangkan kreativitasnya sehingga menghasilkan suatu kreasi maupun gagasan baru dari kegiatan-kegiatan yang ada dalam buku pelajaran.

Menurut Munandar (2002), konsep dan pengembangan kreativitas bisa dilakukan dengan bertitik tolak pada konsep yang dinamakan pendekatan 4P, yaitu Pribadi, Pendorong, Proses, dan Produk. Pendekatan pribadi menekankan pada pemahaman bahwa anak adalah pribadi yang unik. Oleh karena itu, pendidik haruslah menghargai bakat dan minat yang khas setiap anak. Itu berarti, anak perlu diberi kesempatan dan kebebasan mewujudkannya. Pendekatan pribadi meliputi kelancaran berpikir, keluwesan berpikir, elaborasi, orisinalitas, evaluasi, menumbuhkan rasa ingin tahu, imajinatif, tertantang oleh kemajemukan, sikap berani mengambil resiko, dan sikap menghargai.

Kreativitas juga dapat ditinjau dari pendekatan pendorong, yakni suatu kondisi yang memungkinkan anak berperilaku kreatif. Pendekatan pendorong, meliputi dorongan internal berupa bersibuk diri secara kreatif, mewujudkan potensi siswa, dan dorongan eksternal berupa keamanan psikologis dan kebebasan psikologis (Munandar, 2002).

Kreativitas sebagai proses lebih menekankan pada pemahaman kemampuan anak menciptakan sesuatu yang baru, paling tidak menemukan hubungan-hubungan jawaban antar berbagai pendekatan. Pendekatan proses, meliputi persiapan, inkubasi, iluminasi, dan verifikasi.

Pendekatan produk tidak terbatas pada produk komersial, tetapi meliputi keragaman dari benda atau gagasan. Pengertian produk kreatif menurut penelitian ini adalah suatu konsep, ide, benda, dan gagasan yang dihasilkan oleh pribadi kreatif dengan ciri-ciri: baru, berguna dan atau bermanfaat serta dapat dipahami melalui lingkungan yang memberi peluang untuk bersibuk diri secara kreatif.

Hubungan pendekatan pribadi, pendorong, proses, dan produk yang telah dijelaskan akan membentuk pola pengembangan kreativitas. Keempat pendekatan itu (4P) menjadi kriteria dalam mengembangkan kreativitas siswa dikaitkan dengan materi yang ada dalam buku pelajaran KTK sesuai dengan objek dari penelitian ini.

\section{KERANGKA BERPIKIR}

Dalam pengembangan kreativitas ada empat 
pendekatan yang membentuk pola pengembangan kreativitas yaitu pribadi kreatif, pendorong kreatif, proses kreatif, dan produk kreatif. Hubungan keempat pendekatan itulah yang akan membentuk pengembangan kreativitas. Oleh karena itu, keempat pendekatan pengembangan kreativitas itulah yang menjadi kriteria dalam mengembangkan kreativitas siswa dikaitkan dengan buku pelajaran KTK sesuai dengan obyek dari penelitian ini.

Materi-materi yang ada dalam buku pelajaran KTK dapat membantu siswa untuk bisa terlibat dalam pola pengembangan kreativitas. Dengan adanya pengembangan kreativitas dalam buku pelajaran KTK berarti terdapat keselarasan antara bahan pelajaran dalam buku dengan keempat pendekatan pengembangan kreativitas.

\section{METODOLOGI PENELITIAN}

Dilihat dari tujuan dan ruang lingkupnya penelitian ini menggunakan metode studi kasus karena hanya berlaku pada buku pelajaran KTK saja, dengan menggunakan teknik analisis isi. Untuk memperkuat analisis dilakukan juga observasi, wawancara, dan penyebaran kuesioner. Isi buku dianalisis secara deskriptif berdasarkan pendekatan pengembangan kreativitas dengan menggunakan kriteria yang terdapat dalam kisi-kisi penelitian.

\section{HASIL PENELITIAN}

Hasil penelitian menunjukkan bahwa perwujudan unsur pada tiap pendekatan dalam pengembangan kreativitas tidak secara keseluruhan terkandung dalam setiap bab buku pelajaran KTK. Pada pendekatan pribadi yang perwujudannya dapat dilihat dari adanya pertanyaan-pertanyaan yang ada dalam setiap bab menunjukkan bahwa pertanyaanpertanyaan itu dapat melatih siswa berpikir dan berdiskusi sehingga bisa menimbulkan gagasangagasan baru. Namun, tidak hanya pertanyaanpertanyaan itu saja, orisinalitas maupun imajinasi diperlukan dalam setiap bab untuk membentuk siswa menjadi pribadi yang kreatif.

Lebih lanjut, berdasarkan observasi pada buku pelajaran KTK, didapatkan bahwa orisinalitas yang berkaitan dengan mensintesis suatu gagasan serta imajinasi yang berkaitan dengan membayangkan halhal yang belum pernah terjadi dan membuat cerita tentang tempat atau kejadian yang belum pernah dikenal, tidak ada dalam setiap bab. Hal ini disebabkan karena isi materi pada buku pelajaran KTK lebih banyak menganalisis daripada mensintesis teori yang telah dijabarkan dalam materi. Siswa kurang dilatih untuk tugas-tugas yang menuntut sintesis. Begitu pula dengan unsur imajinasi, tugas-tugas yang ada dalam buku tidak mengarahkan siswa untuk membayangkan hal-hal yang belum pernah terjadi. Hal ini demikian karena penulis buku lebih memfokuskan pada penguasaan siswa terhadap materi yang telah dijelaskan daripada menugaskan siswa untuk berimajinasi sehingga membuat siswa tidak terlatih untuk melakukan kegiatan ini. Daya imajinasi siswa kurang didorong pada kegiatan yang ada di buku pelajaran KTK sehingga siswa tidak terbiasa diberikan masalah-masalah yang menuntut pemikiran "mengandaikan" (berimajinasi).

Pendekatan pendorong berkaitan dengan dorongan eksternal dan internal. Dorongan internal dimaksudkan agar siswa memiliki keinginan untuk terlibat dalam berkreasi, dengan memberikan kegiatan yang bisa membuat siswa menyibukkan diri secara kreatif. Berdasarkan observasi pada buku pelajaran KTK didapatkan bahwa siswa dilibatkan dalam kegiatan kreatif seperti prakarya, seni musik, dan seni tari. Selain dikerjakan di sekolah, kegiatan yang ada dalam buku pelajaran KTK dapat dilakukan di rumah. Bahan-bahan seperti lilin, tanah liat, dan kertas memungkinkan siswa membuat macam-macam kombinasi yang menghasilkan aneka ragam ciptaan sehingga kreativitas siswa dapat terlihat melalui ciptaan-ciptaan yang dibuatnya.

Berdasarkan observasi didapatkan bahwa dorongan eksternal yang berupa keamanan psikologis maupun kebebasan psikologis tidak banyak terdapat dalam buku pelajaran KTK. Hanya empat bab yang memiliki pendekatan ini. Hal ini disebabkan buku pelajaran KTK tidak banyak memberikan kesempatan bagi siswa untuk menilai prestasi dan menarik kesimpulan mengenai tugasnya. Guru hendaknya tidak terlalu cepat memberikan penilaian terhadap siswa, apalagi yang bersifat kritik, karena dapat dirasakan sebagai ancaman oleh siswa. Ini tidak berarti bahwa guru tidak boleh menilai kemajuan dan prestasi siswa. Oleh karena itu, sebaiknya buku pelajaran KTK menyediakan sebuah kolom catatan siswa agar siswa bisa menuliskan kesulitan yang dihadapi pada saat pengerjaan tugas dan guru dapat memberikan umpan balik yang menyatakan letak kesalahan siswa dan bagaimana siswa dapat memperbaikinya.

Pendekatan proses berkaitan dengan persiapan, iluminasi, inkubasi, dan verifikasi. Tahap persiapan dimaksudkan untuk membuat siswa tertarik mempelajari materi tersebut, merangsang ingatan siswa mengenai materi bab sebelumnya, dan menyediakan materi pengetahuan yang menunjang Perspektif Ilmu Pendidikan - Vol. 15 Th. VIII April 2007 
penguasaan materi sehingga siswa dapat mempersiapkan diri untuk berpikir dan mencari jawaban terhadap pertanyaan serta kegiatan yang ada dalam buku. Tahap iluminasi ditandai dengan penentuan waktu untuk menyelesaikan setiap bab. Berdasarkan observasi, tahap ini tidak ada dalam buku pelajaran KTK. Hal ini bisa disebabkan karena buku pelajaran KTK memberikan kebebasan bagi guru dalam menentukan waktu untuk menyelesaikan satu pokok bahasan. Tahap inkubasi, penting artinya dalam proses menimbulkan inspirasi yang merupakan titik awal adanya kreativitas. Tahap inkubasi ditandai dengan mengemukakan pertanyaan kreatif dari masalah yang ditemukan. Berdasarkan observasi pada buku didapatkan bahwa tahap inkubasi ada di setiap bab. Tahap ini dapat melatih siswa agar berpikir divergen. Tahap verifikasi ditandai dengan melibatkan siswa pada pelaksanaan evaluasi. Tahap ini sedikit sekali dalam buku pelajaran KTK karena hanya satu bab dalam buku yang mengandung tahap ini.

Pendekatan produk berkaitan dengan produk yang baru, berguna, dan dapat dipahami. Beberapa bab dalam buku mengandung bahan ajar yang menggunakan pendekatan ini. Observasi menunjukkan bahwa hasil karya yang disajikan dalam buku belum pernah dibuat sebelumnya atau merupakan kombinasi dari produk sebelumnya. Pembuatan produk baru yang belum pernah dibuat sebelumnya oleh siswa akan melahirkan produk yang orisinal, dan menimbulkan gagasan-gagasan baru. Kreativitas siswa akan terlihat dari produk yang dibuat apakah memiliki perbedaan dengan temanteman lainnya. Perbedaan yang dimaksud misalnya adalah adanya penambahan warna atau bagian lain pada produk tersebut sehingga lebih menarik.

Pembuatan produk yang merupakan kombinasi dari produk sebelumnya memerlukan kreativitas karena siswa mengkaitkan antara beberapa produk yang ada dengan produk yang belum pernah ada. Gagasan-gagasan baru yang timbul pada produk yang belum pernah dibuat sebelumnya akan bercampur dengan gagasan yang ada pada produk yang sudah ada sehingga produk akan semakin kaya. Indikator produk berguna bagi masyarakat tidak begitu penting dalam produk kreatif. Ada yang menganggap bahwa yang penting produk itu menyenangkan bagi penemunya.

Bila pembicaraan berkisar pada siswa ketika mereka diharapkan kelak dapat menyumbangkan ide kreatifnya bagi peningkatan kualitas hidup, tidak salah bila produk juga dipersyaratkan berguna bagi masyarakat. Akibatnya, siswa diharapkan dapat menciptakan suatu produk yang memiliki nilai guna bagi masyarakat. Hal tersebut akan mendatangkan kebanggaan dan prestasi tersendiri bagi siswa. Bila orang lain dapat mengerti apa yang dibuat siswa, maka mereka akan mengetahui adanya kreativitas pada diri siswa. Orang lain bisa melihat nilai yang berbeda pada produk yang diciptakan oleh siswa. Selain itu, bila siswa bisa mengerti produk yang disajikan dalam buku pelajaran maka siswa akan dapat mengembangkan sendiri produk tersebut sesuai dengan gagasan yang dimiliki siswa. Oleh karena itu, penulis buku sebaiknya menyajikan pembuatan produk yang mudah dimengerti baik oleh orang lain maupun siswa agar orang lain bisa mengerti kreativitas yang dimiliki siswa dan siswa juga bisa mengembangkan produk tersebut dengan gagasan yang dimiliki.

\section{KESIMPULAN}

\section{Kesimpulan}

Kesimpulan penelitian ini adalah sebagai berikut.

1. Perwujudan pendekatan pribadi yaitu orisinalitas dan imajinatif, tidak lengkap terdapat dalam buku pelajaran KTK. Walaupun demikian, penerapan pendekatan pribadi sudah dapat dikatakan mendorong siswa menjadi pribadi yang kreatif dan kreativitas siswa bisa tergali serta berkembang meskipun belum optimal.

2. Perwujudan dari pendekatan pendorong tidak lengkap terdapat dalam buku pelajaran KTK karena dorongan eksternal kurang diberikan pada siswa. Siswa belum dilibatkan pada pelaksanaan evaluasi kerjanya. Pendapat siswa mengenai tugasnya diperlukan dalam pengembangan kreativitas karena jika siswa dihargai pendapatnya diharapkan mereka akan semakin menyukai kegiatan-kegiatan kreatif terutama yang ada dalam buku pelajaran KTK.

3. Perwujudan dari pendekatan proses tidak lengkap ada dalam buku pelajaran KTK karena tahap inkubasi dan verifikasi kurang diterapkan. Tahap inkubasi tidak terdapat dalam buku pelajaran KTK, namun pada proses belajarnya, guru memberikan siswa waktu yang cukup untuk mengerjakan satu pokok bahasan. Dengan demikian penerapan pendekatan proses dapat ditutupi melalui tindakan yang dilakukan guru pada saat mengerjakan tugas. 
4. Perwujudan dari pendekatan produk lengkap terdapat dalam setiap bab, sehingga nantinya siswa diharapkan dapat menyumbangkan potensinya dalam masyarakat dan semakin berkreasi. Walaupun dalam beberapa bab penerapan pendekatan pribadi, pendorong, proses, dan produk tidak lengkap, tetapi sudah dapat dikatakan buku pelajaran KTK dapat menggali dan mengembangkan kreativitas siswa meskipun belum optimal.

\section{Implikasi}

Kesimpulan hasil penelitian ini memberikan implikasi bahwa tidak lengkapnya pendekatan pribadi, pendorong, proses, dan produk dalam buku pelajaran KTK akan membawa dampak kepada pihakpihak berikut.

1. Mahasiswa Jurusan Kurikulum dan Teknologi Pendidikan diharapkan dapat merancang suatu media ataupun metode pembelajaran yang dapat melengkapi kekurangan yang ada dalam buku pelajaran dengan memperhatikan konsep pengembangan kreativitas seperti yang telah dijelaskan dalam penelitian ini.

2. Guru diharapkan dapat melengkapi indikator pada pendekatan pengembangan kreativitas yang tidak ada dalam buku pelajaran dengan pembelajaran di dalam kelas dan hanya terpaku pada hal-hal yang diajarkan dalam buku pelajaran.

3. Kepala sekolah perlu menyediakan sarana dan prasarana yang dapat melengkapi pendekatan pengembangan kreativitas, seperti taman bacaan, ruang kesenian, dan menyelenggarakan pentas seni sebagai penghargaan kepada karya-karya siswa, sehingga siswa merasa dihargai karya-karyanya.

4. Siswa diharapkan dapat menambah pengetahuan mengenai pengembangan kreativitas sehingga dapat diterapkan dalam dirinya.

5. Penulis bahan ajar perlu melengkapi materi yang ada di dalam buku pelajaran KTK dengan mengikuti konsep pendekatan pengembangan kreativitas. Apabila buku pelajaran KTK mengikuti konsep pendekatan pengembangan kreativitas, maka akan ada peluang bagi siswa dalam mengembangkan kreativitasnya dan dapat melatih kemampuan berpikir kreatif siswa.

\section{Saran}

Secara umum, penelitian ini menyarankan agar buku pelajaran KTK dapat mewujudkan pengembangan kreativitas dengan lengkap yaitu dengan menambahkan beberapa kegiatan yang ada di buku pelajaran KTK. Apabila buku tersebut masih seperti yang ada sekarang, maka guru sebaiknya melengkapi kekurangan-kekurangan pada pendekatan-pendekatan pengembangan kreativitas dengan menambahkan kegiatan-kegiatan yang dapat mengembangkan kreativitas siswa.

Secara rinci, peneliti ingin memberikan saran yang dirumuskan sebagai berikut.

1. Kepala sekolah hendaknya lebih teliti dalam memilih dan menentukan buku pelajaran yang digunakan siswa di sekolah, karena apabila tidak cermat dalam menentukan buku yang digunakan oleh siswa bisa menganggu proses pembelajaran. Hal yang bisa dilakukan oleh kepala sekolah dalam memilih dan menentukan buku pelajaran yang akan digunakan di sekolah yaitu dengan melakukan survei terhadap beberapa buku pelajaran yang ada. Survei dilakukan dengan melihat isi dari buku pelajaran apakah bisa memenuhi tuntutan kurikulum yang berlaku. Jika dari sekian banyak buku pelajaran tidak ada yang lengkap sesuai dengan tuntutan kurikulum, maka dilihat dari sedikitnya kekurangan yang ada di buku pelajaran tersebut dibandingkan dengan buku pelajaran lain pada mata pelajaran yang sama. Kekurangan yang ada di buku pelajaran tersebut bisa ditutupi dengan bantuan guru bidang studi.

2. Perlunya penyebarluasan informasi tentang pemahaman akan pentingnya kreativitas dan implementasinya dalam kegiatan belajarmengajar bagi guru, kepala sekolah, dan penulis bahan ajar.

3. Perlunya pemahaman serta penyebarluasan informasi mengenai konsep pengembangan kreativitas pada guru, kepala sekolah, dan penulis bahan ajar.

4. Guru mata pelajaran KTK yang menggunakan buku ini sebaiknya melengkapi hal-hal yang dirasa belum memadai dalam buku pelajaran tersebut. Dalam proses pembelajaran, guru memberikan kesempatan kepada siswa untuk mengeluarkan gagasannya, memberikan suasana aman dan bebas secara psikologis dengan menghindari pemberiaan hukuman, disiplin yang tidak kaku, siswa boleh mempunyai gagasan sendiri dan dapat berpartisipasi secara aktif, serta memberi kebebasan berpikir kreatif.

5. Penulis bahan ajar hendaknya memperhatikan unsur-unsur dalam buku pelajaran KTK dan disesuaikan dengan peranan yang di-harapkan dalam pelajaran KTK seperti yang tercantum 
dalam kurikulum. Unsur-unsur yang tidak ada dalam buku pelajaran KTK dapat dijadikan referensi bagi pengarang buku pelajaran KTK agar dapat melengkapi unsur tersebut, sehingga pengembangan kreativitas dapat terwujud dengan lengkap.

\section{DAFTAR PUSTAKA}

Haryati, Y. dkk. (2003). Peningkatan pembelajaran kerajinan tangan dan kesenian dengan pendekatan kreativitas di Kelas III SDN 2 Borokulon, Purworejo "Laporan Penelitian" Universitas Terbuka, (http://pk.ut.ac.id).

Munandar, S.C.U. (1992). Mengembangkan bakat dan kreativitas anak sekolah. Jakarta: Gramedia.
Pengembangan Kreativitas Dalam... Munandar, S.C.U. (2002). Kreativitas dan keberbakatan: Strategi mewujudkan potensi kreatif dan bakat. Jakarta: PT. Gramedia.

Nashori, H.F. dan Mucharam, R.D. (2002). Mengembangkan kreativitas dalam perspektif psikologi Islam. Jogjakarta: Menara Kudus.

\section{KETERANGAN PENULIS}

Ika Lestari, S.Pd., dilahirkan di Jakarta, Februari 1984. Setelah menyelesaikan pendidikan Strata 1 Jurusan Kurikulum dan Teknologi Pendidikan, FIP UNJ tahun 2006, mengajar sebagai dosen tidak tetap di Jurusan Public Relations, Akademi Komunikasi Bina Sarana Informatika, Jakarta. Di samping itu, sedang menempuh Program Magister Ilmu Komunikasi Universitas Indonesia. 